\title{
Comparison of the Effects of Three Extract Sorts of Soybean DETAM 1 on the Total Cholesterol Level in Balb-C Male Mice
}

\author{
Meilinah Hidayat*, Khie Kiong ${ }^{1}$, Christina Melissa Siswanto ${ }^{2}$
}

\begin{abstract}
${ }^{1}$ Biology Department, Faculty of Medicine, Maranatha Christian University, JI. Prof. Drg. Suria Sumantri No. 65, Bandung, Indonesia ${ }^{2}$ Faculty of Medicine, Maranatha Christian University, Jl. Prof. Drg. Suria Sumantri No. 65, Bandung, Indonesia "Correspondence: Nutrition Department, Faculty of Medicine, Maranatha Christian University, JI. Prof. Drg. Suria Sumantri No. 65, Bandung, Indonesia

e-mail: mellahidayat@yahoo.com
\end{abstract}

\section{Abstract}

B ACKGROUND: Hypercholesterolemia is a major risk factor for coronary heart disease. Pharmacological treatment of hypercholesterolemia are known to have side effects, hence the need for an alternative medicine, like herbal medicine, such as soybean as an example. Research objective is to compare the effects of ethanol extract, protein extract, and ethyl acetate fraction of soybean tempeh Detam-1 on the total serum cholesterol level of male mice.

METHODS: This study was a laboratory experimental study with Completely Randomized Design (CRD) method. Twenty five Balb-C strain male mice were allocated into five groups, namely: the negative-control (aquabidest), the positive-control (simvastatin), ethanol extract, protein extract and ethyl acetate fraction of the soybean tempeh Detam-1 and all were fed with high cholesterol containing food for 31 days. Starting on the 18 th day all groups were treated for 14 days. The observed parameter was the total serum cholesterol level. The data of the study results were analyzed with ANOVA, followed by Tukey HSD test.

RESULTS: There were significant differences between treatment groups and the negative-control $(\mathrm{p}=0,004)$. The reduction of the total cholesterol level of soy ethanol extract was $35,11 \% \pm 15$, the ethyl acetate fraction of soybean tempeh $26,48 \% \pm 17$, and soy protein extract was

\section{Abstrak}

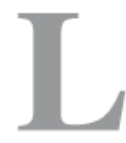

ATAR BELAKANG: Hiperkolesterolemia merupakan faktor risiko utama penyebab penyakit jantung koroner. Penatalaksanaan secara farmakologis terhadap hiperkolesterolemia diketahui memiliki beberapa efek samping, sehingga dipikirkanlah alternatif penggunaan tanaman obat, yaitu kedelai. Tujuan penelitian adalah untuk membandingkan efek ekstrak etanol, ekstrak protein biji kedelai, dan fraksi etil asetat tempe kedelai Detam 1 terhadap kadar kolesterol total serum mencit galur Balb-C jantan.

METODE: Eksperimental laboratorium sungguhan dengan rancangan acak lengkap (RAL). Sebanyak 25 ekor mencit galur Balb-C jantan dibagi menjadi 5 kelompok, kelompok kontrol negatif (akuabides), kontrol positif (simvastatin), estrak etanol, dan ekstrak protein biji kedelai dan fraksi etil asetat tempe Detam 1. Setiap kelompok diinduksi pakan tinggi kolesterol selama 31 hari dan mulai hari ke-18 diberi perlakuan selama 14 hari. Parameter yang diamati adalah kadar kolesterol total serum. Data dianalisis menggunakan ANAVA satu arah dilanjutkan dengan uji Tukey HSD.

HASIL: Terdapat perbedaan signifikan antara kelompok kontrol negatif dengan kelompok perlakuan $(p=0,004)$. Persentase penurunan kolesterol total kelompok ekstrak etanol $35,11 \% \pm 15$, fraksi etil asetat tempe kedelai Detam $126,48 \% \pm 17$, dan ekstrak protein biji kedelai $15,33 \% \pm$ 
$15,33 \% \pm 33,1$, and no significant difference was noted in the positive-control group (simvastatin).

CONCLUSION: The ethanol extract of soybean seed, protein extract of soybean seed, and ethyl acetate fraction of soybean tempeh Detam-1 have the same effect as do simvastatin, and ethanol extract of soybean seed is the most effective substance for lowering total serum cholesterol in Balb-C male mice.

KEYWORDS: Hypercholesterolemia, ethanol extract, protein extract and ethyl acetate fraction, soybean Detam-1

Indones Biomed J 2012; 4 (3): 164-173
33,1 dan tidak memiliki perbedaan yang signifikan dengan kelompok kontrol positif (simvastatin).

KESIMPULAN: Ketiga jenis ekstrak memiliki efek yang setara dengan simvastatin dan ekstrak etanol biji kedelai Detam 1 paling baik dalam menurunkan kadar kolesterol total serum mencit galur Balb-C jantan yang diinduksi pakan tinggi lemak.

KATA KUNCI: Hiperkolesterolemia, ekstrak etanol, ekstrak protein, fraksi etil asetat tempe, kedelai Detam 1

Indones Biomed J 2012; 4 (3): 164-173

\section{Introduction}

Cardiovascular diseases have become the primary death cause in the world. According to World Health Organization (WHO), coronary heart disease (CHD) causes $60 \%$ mortality of cardiovascular cases (1).

Hypercholesterolemia is a condition with excess of cholesterol level in the blood, and this condition can lead to cardiovascular diseases such as atherosclerosis, coronary heart disease (CHD) and hypertension (2).

Cholesterol lowering agents like the statins are commonly used to treat this condition. But a long usage of the drugs can cause side effects like gastro intestinal disturbances, headaches, rashes, rhabdomyolisis, and chronic kidney disease (3).

Reducing body weight is believed to be able to improve the prognosis of cardiovascular diseases. Therefore, we need to discover a type of treatment that can reduce bodyweight and lower blood lipid level, that has fewer side effects. Among the natural products, we expect to find a drug that has the antiobesity and anticholesterolemia effects with fewer side effects. One potential candidate is soybean. Isoflavones and protein are two major components in soybean. Several studies have shown that isoflavones and high quality protein in soybean have the effects of reducing body weight and lowering lipid level, which can lower total cholesterol, LDL, triglycerides, and slightly increase HDL (3).

Detam 1 soybean is a high-quality seed that has been approved by the National Seed Board with Decree of the Minister of Agriculture in November 2008 (4). Previous study showed the extract that caused most prominent reduce in food intake in Wistar rats was protein extract of Detam 1 soybean seed. But when it was measured by HPLC it showed no isoflavone at all (5). We concluded that the reducing food intake effect was not due to isoflavone, but by other active substance, namely $\beta$-Conglycinin subunit $\beta$. $\beta$-Conglycinin subunit $\beta$ has the strongest activity to stimulate Cholecystokinin (CCK), a gut hormone-that can reduce body weight and is assumed to be able to lower blood lipid level. Using SDS PAGE and CBB staining, we measured the highest level of $\beta$-conglycinin that was found in protein extract of Detam 1 soybean seed, using Deak method (6).

Another reference stated that lecithin in soybean is good for improving dyslipidemia (3). Ethanol extract of soybean seed Detam 1 contains phenol, flavonoid, alkaloid, triterpenoid-steroid, saponin, quinone and tannin and assumed to have a high content of lecithin, because it causes significant effect to reduce body weight of Wistar rats in a 14 day treatment, but it does not cause high CCK level, indicating it has low $\beta$-Conglycinin level, and when measured using HPLC it contains only low level of isoflavones (7).

Results of a previous study that measured isoflavones level of 24 sorts of soybean extracts using HPLC, the highest concentration was in fraction of ethyl acetate. The level of Daidzein in fraction ethyl acetate of soybean tempeh Detam 1 was $0.093 \%$ and Genistein was $0.015 \%$ (5). During the fermentation process, decomposition process occurred in which the complex compounds of isoflavone turned into active aglycone isoflavones. This made the processed products have higher biological activity (8). 
Not very many studies on the effects of fermented soy products like tempeh have yet been done. The content of a certain extract of soybean is thought to be able to lower the lipid profile, but which content is the best still needs to be studied.

\section{Methods}

\section{Materials}

The Soybean Detam 1 variety was first planted in Balai Penelitian Kacang dan Umbi-umbian (Balitkabi) plantation in Malang. This variety has been developed from a cross of 9837 introduction variety $x$ Kawi variety. Cultivated Detam 1 variety produces 2,51 ton per acre, the seeds are harvested in 84 days. This soybean has a yellow flesh seed but covered with hard black seed skin. It contains 45,36 $\%$ protein (percentage of dry weight), much greater than the other varieties. This variety was approved as a high quality soybean by Minister of Agricultural decree no 240/Kpts/SR.120/3/2008, dated March 6 $6^{\text {th }} 2008$ (4).

\section{Methodology}

The research method was experimental comparative laboratory study with Completely Randomized Design (CRD). Serum total cholesterol was measured using the CHOD-PAP (Cholesterol Oxidase-p-aminophenazone) by enzymatic colorimetric test principle. Statistical analysis was done using variant analysis test (ANOVA) one-way with $\alpha=0.05$ and followed by Tukey HSD test with $95 \%$ confidence level, the level of significance was based on the $\mathrm{p}$ value of $\leq 0.05$.

\section{Soybean Fermentation Procedures to Make Tempeh $(8,9)$}

We made tempeh ourselves by the following procedures. The procedures included 8 step processes: boiling, seed skin peeling, soaking, washing, steaming, giving the yeast, packaging, and stewing. Detam 1 and Wilis soybean seed were weighed 500 grams each, and then boiled. The next process was peeling the seed skin to enable the mycellium to break off the epidermis which contains horny material. Soaking was the next step that made an acid condition. The soybean seeds (without skin) were then washed until they were not sleek. Then the materials were steamed until the seeds became soft and well-cooked.

After the yeast or tempeh inoculum was given onto the soybean seeds, the materials were cooled. The dosage was 1 gram of inoculum for 1 kilogram soybean seed. The soybean seeds, which were already mixed with inoculum, were packed in plastic bags. Then the packages of the materials were incubated for 2 days at $18-24^{\circ}$ Celcius with free airflow $(8,9)$. From 500 gram of raw soybean seeds we produced 650 gram tempeh.

\section{Steps to Make Protein Extract of Soybean Detam 1 Using Deak's Method (10)}

Defatted soy flour of $100 \mathrm{~g}$ was extracted using deionized water with a ratio of $1: 15(\mathrm{w} / \mathrm{v})$ at $\mathrm{pH} 8.5$ adjusted with 2 $\mathrm{N} \mathrm{NaOH}$. The slurry was stirred for $1 \mathrm{~h}$ and centrifuged at $14,000 \mathrm{~g}$ and $15 \mathrm{o} \mathrm{C}$ for $30 \mathrm{~min}$. The protein extract (first protein extract) was decanted (Figure 1).

The extract was then added with sufficient $\mathrm{NaHSO}_{3}$ and $\mathrm{CaCl}_{2}$ to obtain concentration of either $\mathrm{SO}_{2}$ and $\mathrm{Ca}_{2}+$ to $5 \mathrm{mM}$ and the $\mathrm{pH}$ was adjusted to 6.4 with $2 \mathrm{~N} \mathrm{HCl}$. The slurry was stored at $4^{\circ} \mathrm{C}$ for $12-16 \mathrm{~h}$. The slurry was centrifuged at $14,000 \mathrm{~g}$ for $30 \mathrm{~min}$ at $4^{\circ} \mathrm{C}$. A glycinin-rich fraction was obtained as the precipitated curd, which was neutralized and treated as described in the Wu procedure. The supernatant (second protein extract) was adjusted to $\mathrm{pH} 4.8$ with $\mathrm{HCl}$, then stirred for $1 \mathrm{~h}$ and centrifuged at $14,000 \mathrm{~g}$ and $4^{\circ} \mathrm{C}$ for $30 \mathrm{~min}$. A $\beta$ conglycinin-rich fraction was obtained as the precipitated curd and treated as described previously. The amount of supernatant (whey) was determined and sampled.

Freeze-drying steps were modified to evaporation process in cycling evaporator at $30^{\circ} \mathrm{C}$ until the solution extracts became thick liquid. Samples were placed in sealed containers and stored at $4^{\circ} \mathrm{C}$ until the analysis.

There are two steps in Deak's procedure i.e. D4C (in $4^{\circ} \mathrm{C}$ ) and DRT (at $25^{\circ} \mathrm{C}$ ). The Deak $\beta$-conglycininrich fraction $\mathrm{D} 4 \mathrm{C}$ (the methods performed in this study) comprises $23.1 \%$ of the solids, $37.1 \%$ of the protein and $37.5 \%$ of the isoflavones in the initial soy flour. Protein purity is $>80 \%$. The D4C method produces $85.6 \% \beta$ conglycinin and $14.4 \%$ glycinin. The $\beta$-conglycinin subunit consists of $27.3 \%$ subunit $\alpha^{\prime}, 38.0 \%$ subunit $\alpha$, $34.7 \%$ subunit $\beta$ (10). 


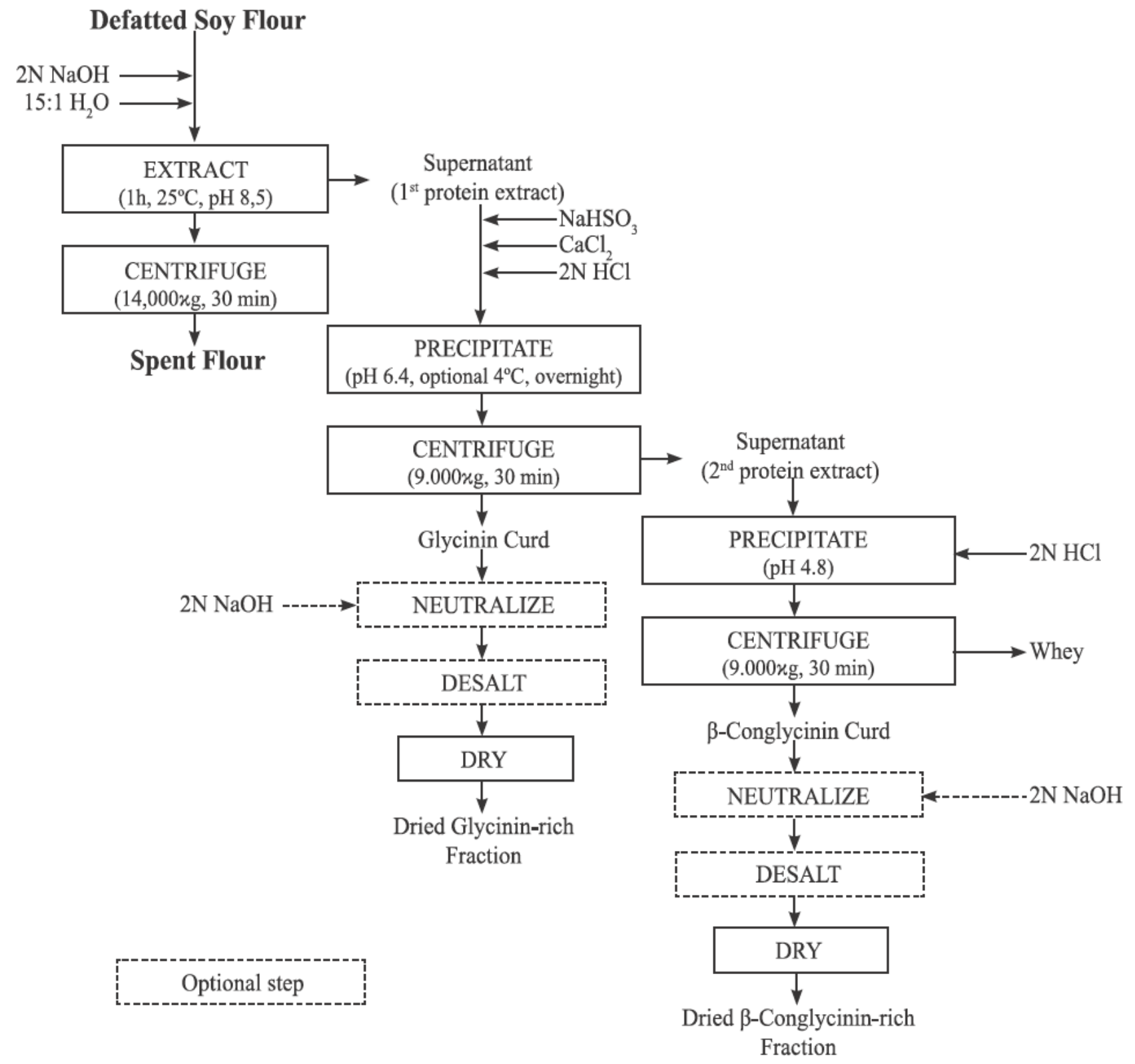

Figure 1. Deak's Method of Protein Extraction of Soybean. 
Procedures to make Ethanol Extract (11).

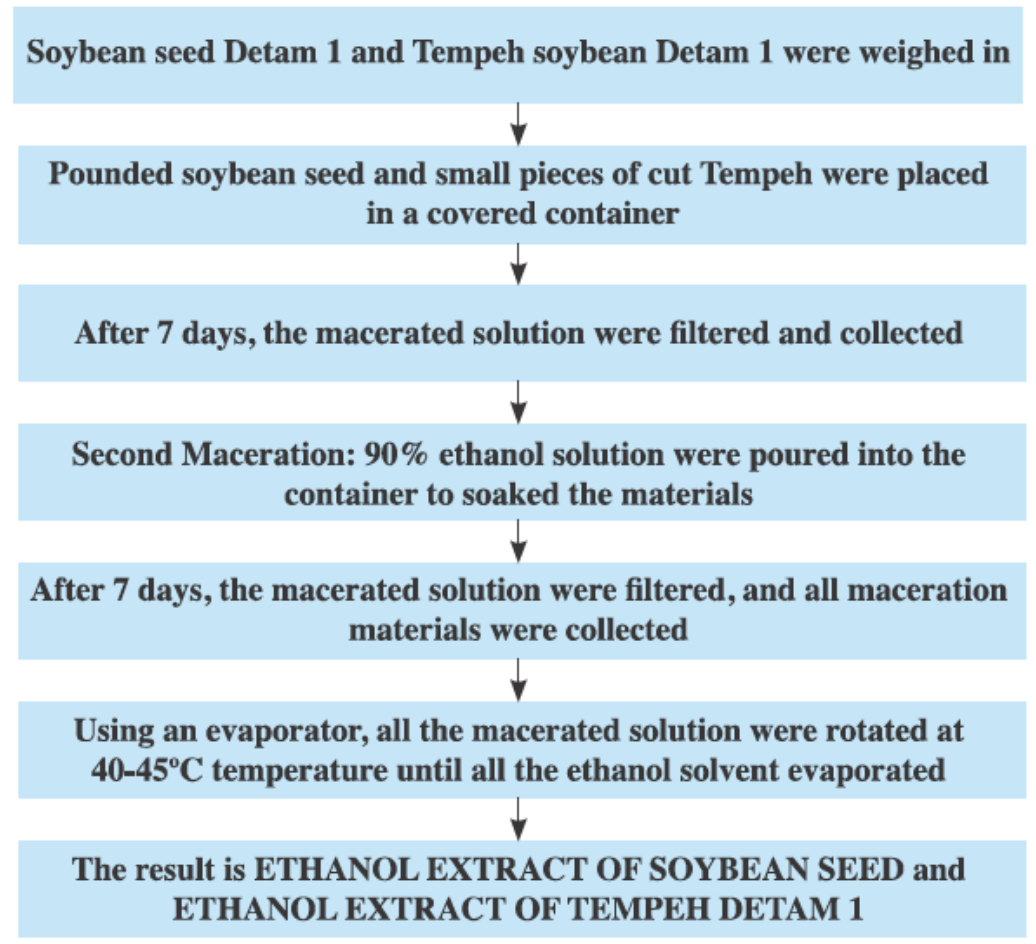

Figure 2. Extraction of Soybean using Ethanol $90 \%$.

Procedures to make Fractionated Ethyl Actetate (EtoAc) (11).

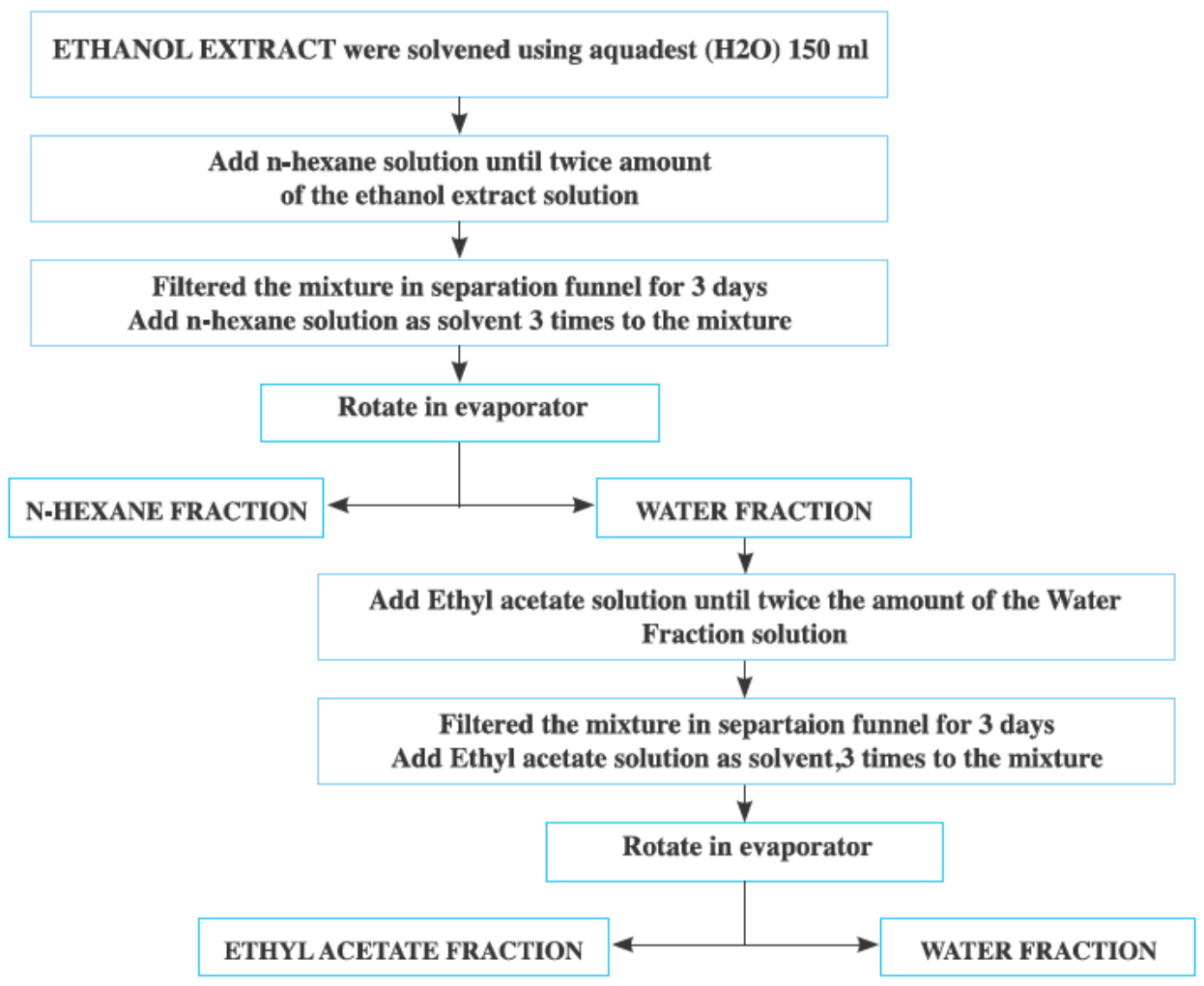

Figure 3. Fractionation of Soybean using Ethyl Acetate solution 


\section{Subjects}

Twenty five male mice Balb-C strains, 8-week-old with average weight of 20 grams, obtained from the Laboratory Animal Research, Research Center for Medical Sciences (PPIK), Faculty of Medicine, Maranatha Christian University, Bandung. This study was approved for ethical clearance by the Ethical Committee of Maranatha Christian University (No.53/KEP FK UKM-RSI/IV/2011).

\section{Place and Time}

Place: Medical Science Research Center (MSRC), Faculty of Medicine, Universitas Kristen Maranatha, Bandung. The time of the study was December 2010, November 2011

\section{Working Procedures}

All the subjects of mice were adapted for 7 days, then the 25 mice were randomly divided into 5 groups $(n=5)$ : NC group (negative control), PC group (positive control) and the P1 ethanol extract of Detam 1 soybean seed (EEDS), the P2 fraction ethyl acetate tempeh Detam 1 (FEATD), and P3 group protein extract Detam 1 soybean (PEDS). Then each group was fed high cholesterol food ad libitum for 31 days. The composition of High Cholesterol feed can be seen in Table 1. Each mice was weighed every morning at 8.00 a.m.

After hypercholesterolemia condition was achieved, at day 18th the groups were started to be treated for 14 days. The dosage for treatment groups was modified and converted from the significant dose in the previous study for lowering body weight in the Wistar Rats $250 \mathrm{~g}$ (ethanol extract $20 \mathrm{mg} / \mathrm{kgBW}$, ethyl acetate fraction tempeh $20 \mathrm{mg} /$
$\mathrm{kgBW}$, protein extract $20 \mathrm{mg} / \mathrm{kgBW}$ ), given to the mice orally via intra gastric tube once a day every morning at 09.00 a.m

- NC Group: $0.2 \mathrm{~mL}$ of distilled water (aquabidest)

- PC Group: simvastatin $0.026 \mathrm{mg} /$ day / in $0.2 \mathrm{~mL}$ of distilled water

- P1 Group: EEDS $1.82 \mathrm{mg} / \mathrm{day} / \mathrm{in} 0.2 \mathrm{~mL}$ of distilled water.

- P2 Group: FEATD $1.82 \mathrm{mg} /$ day/in $0.2 \mathrm{~mL}$ of distilled water.

- P3 Group: PEDS $1.82 \mathrm{mg} /$ day/in $0.2 \mathrm{~mL}$ of distilled water.

Measurement of serum total cholesterol levels was done 3 times, first on day- 0 as the initial phase for the baseline data, day-13th to determine serum cholesterol levels, and day-32th to determine the effects of soy extract.

\section{Collection of samples at day $32^{\text {th }}$}

Mice were fasted for 12 hours before preparation. Blood samples were taken from the orbital sinus using microcentrifuge tubes and numbered according to the numbers of the mice.

\section{Measurement of Total Serum Cholesterol and Data Analysis}

Serum total cholesterol was measured using enzymatic colorimetric principles of CHOD-PAP method (Cholesterol Oxidase-p-aminophenazone) (13). Statistical analysis was done using one-way (ANOVA) with $\alpha=0.05$, followed by difference test of Tukey HSD with $95 \%$ confidence level, the level of significance was based on the $p$ value of $\leq$ 0.05 .

Table 1. Composition of High Cholesterol Feed

\begin{tabular}{lll}
\hline Composition & Calorie in $\mathbf{1 0 0 \mathrm { g }}$ & \multicolumn{3}{c}{ Amount for this study } \\
\hline Wheat flour & $365 \mathrm{kkal}$ & $1 \mathrm{~kg}=365 \mathrm{kkal} \times 10=3650 \mathrm{kcal}$ \\
Fish pellet & $320 \mathrm{kkal}$ & $0,5 \mathrm{~kg}=320 \mathrm{kkal} \times 5=1600 \mathrm{kcal}$ \\
Pur/ Fat & $320 \mathrm{kkal}$ & $1,5 \mathrm{~kg}=320 \mathrm{kkal} \times 15=4800 \mathrm{kcal}$ \\
Goat Fat & $630 \mathrm{kkal}$ & $2 \mathrm{~kg}=630 \mathrm{kkal} \times 20=12600 \mathrm{kcal}$ \\
Duck Egg yolk & $398 \mathrm{kkal} / 3$ eggs & $10 \mathrm{butir}=398 \mathrm{kkal} \times 3,3=1313,4 \mathrm{kcal}$ \\
Butter & $725 \mathrm{kkal}$ & $1 \mathrm{~kg}=725 \mathrm{kkal} \times 10=7250 \mathrm{kcal}$ \\
& & \\
& TOTAL WEIGHT & $6.330 \mathrm{~kg}=6330 \mathrm{~g}=31213.4 \mathrm{kcal}$
\end{tabular}




\section{Results}

Table 2. Mean body weight of the mice after high cholesterol feeding and treatment

\begin{tabular}{ccccc}
\hline Groups & $\begin{array}{c}\text { Initial BW/ } \\
\text { in } \mathbf{~ g}\end{array}$ & $\begin{array}{c}\text { After } \mathbf{1 8} \text { days HC } \\
\text { Feeding/in g }\end{array}$ & $\begin{array}{c}\text { After 14 days } \\
\text { Treatment/in g }\end{array}$ & $\begin{array}{c}\text { Percentage } \\
\text { Decrease }\end{array}$ \\
\hline NC & 20.17 & 20.13 & 20.48 & +1.7668 \\
PC & 21.52 & 23.70 & 19.64 & -18.86 \\
P1 & 17.45 & 21.84 & 17.55 & -24.54 \\
P2 & 19.66 & 22.89 & 18.15 & -24.081 \\
P3 & 19.28 & 22.33 & 17.63 & -24.32 \\
\hline
\end{tabular}

Table 3. Data of mean total serum cholesterol levels (mg/dL)

\begin{tabular}{lccccc}
\hline $\begin{array}{l}\text { Treatment } \\
\text { Groups }\end{array}$ & $\begin{array}{c}\text { Base } \\
\text { (day 0) }\end{array}$ & $\begin{array}{c}\text { Start } \\
\text { (day 18) }\end{array}$ & $\begin{array}{c}\text { End } \\
\text { (day 32) }\end{array}$ & $\begin{array}{c}\text { Percentage } \\
\text { Decrease }\end{array}$ & $\begin{array}{c}\text { Deviation } \\
\text { Standard }\end{array}$ \\
\hline NC & 131.6 & 121.2 & 140.6 & -18.83 & 23.1 \\
PC & 118.4 & 165.4 & 125.2 & 24.77 & 2.35 \\
P1 & 103.4 & 128.6 & 79.8 & 35.11 & 15 \\
P2 & 122.8 & 168.4 & 124.6 & 26.48 & 17.04 \\
P3 & 103.6 & 160 & 126.2 & 15.33 & 33.1 \\
\hline
\end{tabular}

NC:negative control. induced high-cholesterol feeding and administered distilled water PC:positive control. induced by high-cholesterol feeding and administered Simvastatin P1:Induction of high cholesterol feeding and administered ethanol extract of soybean seed P2:Induction of high cholesterol feeding and administered ethyl acetate fraction tempeh P3:Induction of high cholesterol feeding and administered soybean protein extract

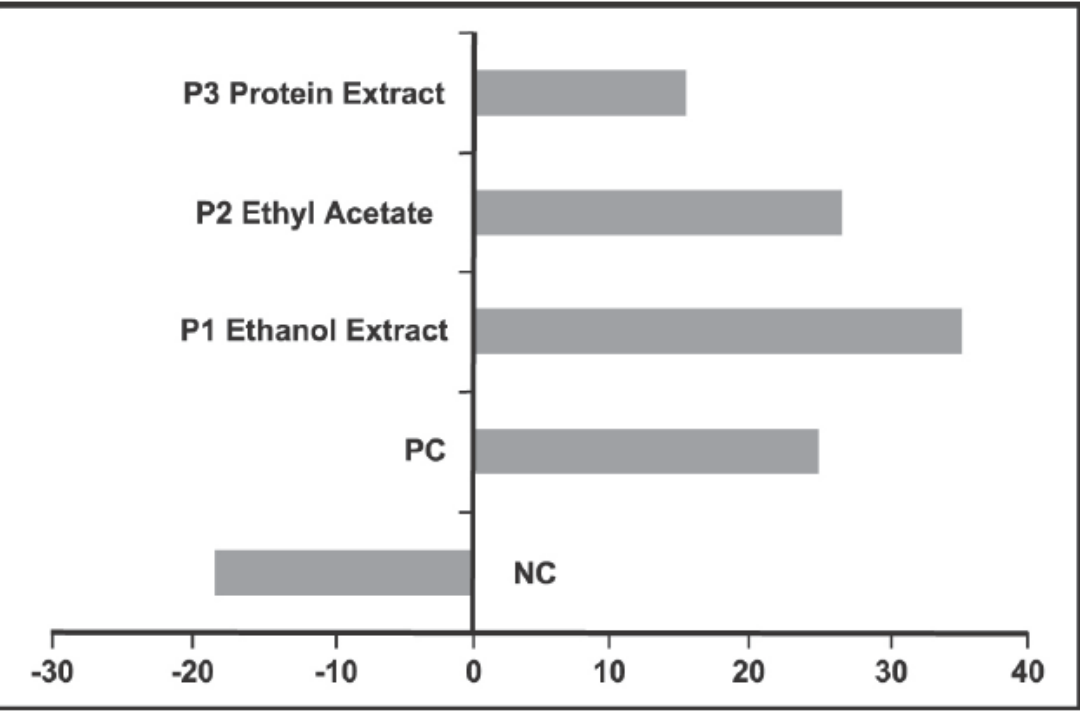

Figure 4. Percentage of Cholesterol Level After Treatment 


\section{Analysis of Variance (ANOVA) Test Results}

After data were analyzed by ANOVA the results obtained $p$ value $=0.005(\alpha=0.05)$. The percentage reduction in total cholesterol levels showed highly significant difference (p $<0.01$ ) among the treatment groups in the minimal 1 pair of group.

The results showed decrease in total serum cholesterol levels in the PC group that was given simvastatin $(24.77 \%)$, and the NC group given distilled water showed an increase in total serum cholesterol levels by $18.83 \%$. There was a significant difference between them $(\mathrm{p}=0.005)$. It can be assumed that this study was valid. The treatment groups (P1 ethanol extract Detam 1, P2 fraction ethyl acetate of tempeh Detam 1 and P3 soybean protein extract, showed significant difference from the $\mathrm{NC}$ group. It can be assumed that all treatment gave positive results in lowering cholesterol level. The highest decrease in the percentage of cholesterol level was seen in the ethanol extract $(35.11 \%)$. followed by ethyl acetate fraction $(26.48 \%)$, the PC group simvastatin $(24.77 \%)$, and protein extracts $(15.33 \%)$.

Then we continued analysis using Tukey HSD test to know which groups were different, as can be seen in Table 4.

The statistical analysis by Tukey HSD method with $\alpha=0.05$, when compared with the NC group, showed a significant difference $(\mathrm{p}<0.05)$ with all treatment groups $(\mathrm{P} 1, \mathrm{P} 2, \mathrm{P} 3)$. The highly significant difference $(\mathrm{p}=0.001)$
Table 4. Tukey HSD Test Results

\begin{tabular}{|c|c|c|c|c|}
\hline NC & PC & P1 & P2 & P3 \\
\hline NC & $p=0.005^{\star *}$ & $p=0.001^{\star \star}$ & $p=0.003^{* *}$ & $p=0.020^{\star *}$ \\
\hline PC & & $p=0,931$ & $p=1,000$ & $p=0,949$ \\
\hline P1 & & & $p=0,963$ & $p=0,569$ \\
\hline $\mathrm{P} 2$ & & & & $p=0,911$ \\
\hline P3 & & & & \\
\hline
\end{tabular}

was found in the group treated with ethanol extract soybean seed of Detam 1.

The treatment of P1, P2, P3 when compared with the PC group (simvastatin) showed no significant difference. This indicated that ethanol extract, ethyl acetate fraction of soy tempeh, and soybean protein extract had equal potential to Simvastatin for lowering total cholesterol levels. The group treated with P1 (ethanol extract of soybean) had no significant difference when compared with the P2 (fraction ethyl acetate tempeh Detam 1) and P3 (protein extract). It can be concluded that all treatment groups had a similar effect in lowering total serum cholesterol levels, as clearly shown in Figure 5.

\section{Ethanol Extract of Detam 1 has the greatest tendency of decreasing effect for cholesterol}

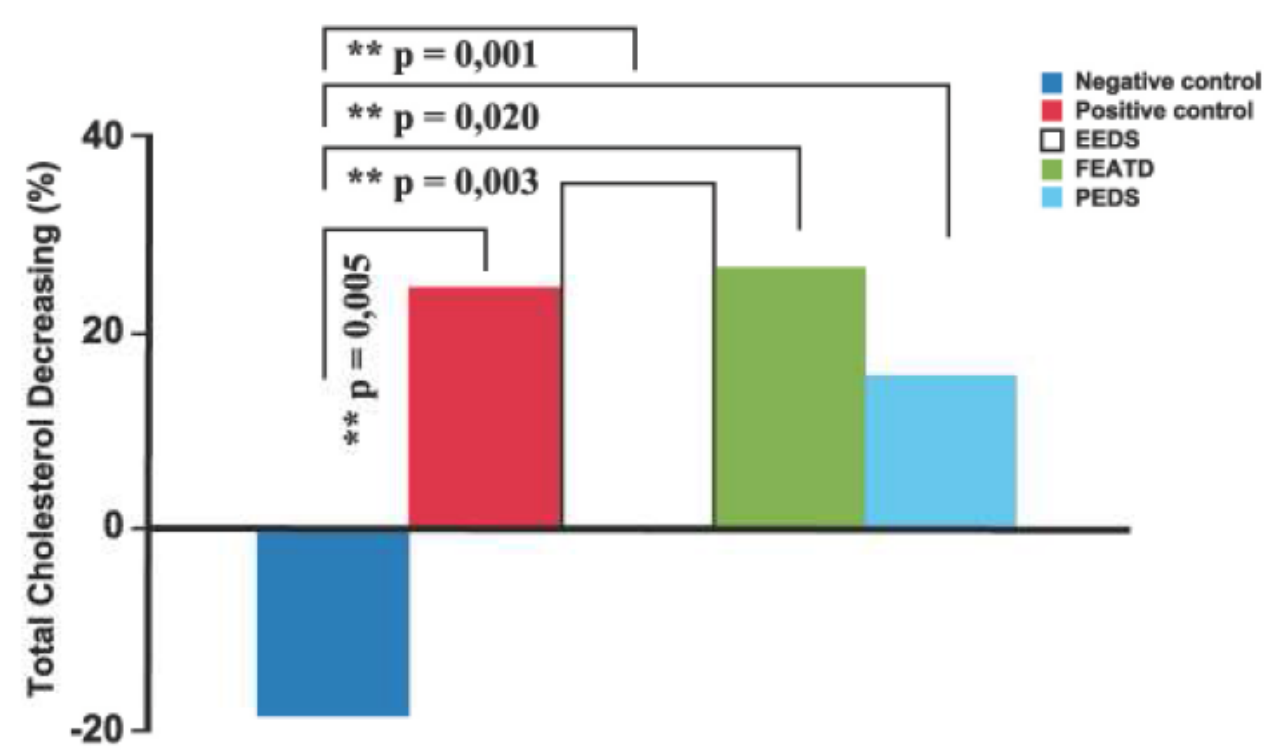

Figure 5. Tukey HSD Test in Percentage Total Cholesterol Decrease After Treatment 


\section{Discussion}

The results showed that treatment groups and Positive Control (PC) group were significantly different from Negative Control (NC) group. So the results of this study were valid, although the $\mathrm{NC}$ group showed confusing result. After being induced with high cholesterol feed for 18 days, the level of cholesterol serum in the NC group decreased from $131.6 \mathrm{mg} / \mathrm{dL}$ to $121.2 \mathrm{mg} / \mathrm{dL}$. This condition might be caused by different activity of the mice in NC group cage. Each cage of groups contained 5 mice and added 1 mouse (20\%) as reserve. In the NC group, on the day 5th, two of the mice did not eat and died, so we added 2 mice to replace. It is possible that the new mice made a different condition in that cage that decreased the appetite of the other mice resulting in decreased body weight from 20.17 $\mathrm{g}$ to $20.13 \mathrm{~g}$, and lowered cholesterol level from $131.6 \mathrm{mg} /$ $\mathrm{dL}$ to $121.2 \mathrm{mg} / \mathrm{dL}$. We realized that there were limitations in this study, for example, one group treatment of mice was put together in one cage and the duration of treatment was too short, only 14 days.

In 2003, Bhathena et al. conducted an experiment on obese mice for six months. The mice were fed on diet of soy protein and flaxseed meal. The study showed a significant reduction in total cholesterol by $41 \%(\mathrm{p}<0.05)$. The concentration of soy protein was used to contain $234.9 \mathrm{mg} / \mathrm{kg}$ of total isoflavones. Isoflavones have active compounds such as genistein and daidzein that play a role in decreasing total cholesterol levels (14).

The highest concentration of isoflavones was found in the fraction ethyl acetate (P2) while the highest concentration of $\beta$-conglycinin was in soybean protein extract Detam 1 (P3) (6). The mechanism of isoflavones in lowering the cholesterol level is similar to that of statin, i.e. by inhibiting the enzyme HMG-CoA reductase. The mechanism of $\beta$-conglycinin is by reducing appetite and food intake through the activity of CCK (Cholecystokinin) $(15,16)$. CCK plays a central role in lowering lipid profile by stimulate pancreatic acinar cells that secrete digestive enzymes like cholesterolesterase. Cholesterolesterase functions to hydrolyze cholesterol, cholesterol esters, and triglyceride (17). In this study, ethanol extract of soybean Detam 1 had the best effect in lowering total cholesterol serum. The result showed the highest decrease in the percentage of cholesterol level $(35.11 \%)$. Based on the previous study that compared many sorts of extracts, the ethanol extract of tempeh Detam 1 had $0.090 \%$ of isoflavones (Genistein), while ethanol extract of soybean seed Detam 1 contained low level of isoflavones, but it contained phenol, flavonoid, alcaloids, triterpenoidsteroid, quinone, saponins dan tannin, which can act as antioxidants agent (4). Ethanol extract is estimated to contain several active components in limited quantities, such as Anti Nutrition Factors (ANF) namely trypsin inhibitor, Bowman-Birk inhibitor, and phytic acid. Each component has a specific mechanism of hypocholesterolemic effects. Mechanism actions of trypsin inhibitor and Bowman-Birk inhibitor in lowering cholesterol levels were similar to the mechanism of $\beta$ conglycinin, namely by increasing the secretion of CCK. Then CCK stimulates bile acid synthesis to digest cholesterol from the digestive tract. Mechanism of phytic acid is by inhibiting the absorption of the food in gastrointesinal tract and lowering $\mathrm{Zn}$ levels in the blood so that the ratio of zinc to copper will decline and subsequent blood cholesterol levels will decrease. Saponin's mechanism in lowering cholesterol levels is by increasing the excretion of bile in faeces (18). While the mechanism action of flavonoids is similar to that of isoflavones and statins, which can lower total cholesterol by inhibiting the enzyme HMG-CoA reductase $(14,19)$. HMG-CoA reductase is a key enzyme in synthesis process of cholesterol in human body.

It has been proven that the differences in the manufacturing process of the extracts procedure or soy protein isolate (SPI) produces different integrity of the protein subunits or active substance that may affect the response and effect of the biological function of the extracts. Therefore, an adequate characterization of soy extracts and soy protein such as integrity testing and measurement of the amount of each subunit would be beneficial so that the research results can be compared between one another $(20,21)$.

The highest content of ethanol extract of soybean was assumed to be flavonoid, lecithin and saponins $(3,4)$. Ethanol acts as the most polar solvent in the first step to make an extract, that is capable of taking out many active substances, like flavonoid, saponins and other secondary metabolites from the soybean (4). Therefore, this extract gave the best result in this study.

\section{Conclusions}

\section{Conclusions:}

- The ethanol extract of soybean seed, protein extract of soybean seed, and ethyl acetate fraction of soybean tempeh Detam-1 have the same effect with simvastatin. 
- Ethanol extract of soybean Detam-1 is the most effective substance in lowering total serum cholesterol of Balb-C male mice that were induced high cholesterol feeding.

\section{Suggestions:}

- The content levels of lecithin and choline in the soybean extracts should be further studied.

- Further study and clinical trial with greater sample and a longer period of time is still needed.

\section{Acknowledgements:}

We would like to thank Lembaga Penelitian dan Pengembangan Masyarakat (LPPM) and Maranatha Christian University for supporting this study with funds.

\section{References:}

1. World Health Organization. WHO World Health Organization Report 2000. Genewa : 2001.

2. Ardiansyah. 2005. Penyakit jantung koroner. www. medicastore.com. 6 Januari 2011.

3. Knopp R.H. Drug treatment of lipid disorder. N Engl J Med 1999; 341: 498-511.

4. Surat Keputusan Menteri Pertanian 2008. Lampiran Keputusan Menteri Pertanian Nomor 240/Kpts/SR 120/3/2008. Tanggal 6 Maret 2008.

5. Hidayat M. Kurnia D. Sujatno M. Sutadipura N. Setiawan. 2010. Perbandingan kandungan makronutrisi dan isoflavon dari kedelai Detam 1 dan Wilis serta potensinya dalam menurunkan berat badan. Bionatura. Journ of Biol. Phys.2010; 12: 5-13.

6. Hidayat M. Kurnia D. Sujatno M. Sutadipura N. Setiawan. Faried A. $\beta$-conglycinin Content Obtained from Two Soybean Varieties Using Different Preparation and Extraction Methods. HAYATI. Journ of Bio.Sci. 2011; 18 : $37-42$.

7. Hidayat M. Sujatno M. Sutadipura N. Setiawan. Effect several soybean (Glycine Max L. Merr) extracts to food intake, body weight and cholecystokinin plasma in rats. Journ of Physiol Ind.2009; 8: 151-8.
8. Hermana. Karmini M. The development of tempe technology. In: Agranoff J. editor. The complete handbook of tempe: The unique fermented soyfood of Indonesia. American Soybean Association. 1999. p.81-92

9. Santoso HB. 2003. Pembuatan tempe dan tahu kedelai bahan makanan bergizi tinggi. Ed 10. Jogjakarta. Kanisius.

10. Deak NA. Murphy PA. Johnson LA. Characterization of Fractionated Soy Proteins Produced by a New Simplified Procedure. J Amer Oil Chem Soc 2007; 84: 137-49 DOI 10.1007/s11746-006-1017-1.

11. Prawiroharsono S. Prospek dan manfaat isoflavon untuk kesehatan. Direktorat Teknologi Bioindustri. Badan Pengkajian dan Penerapan Teknologi. 2010.

12. Direktorat Gizi Departemen Kesehatan RI. 1981. Daftar Komposisi Bahan Makanan. Pemeliharaan Hewan Coba. Jakarta : Bhratara Karya Aksara.

13. Roche Diagnostics. CHOL cholesterol CHOD-PAP. Indianapolis : Roche Diagnostics. 2005.

14. Bhathena SJ. Ali A. Handenschild C. Latham P. Ranich T. Mohamed Al. et al. Dietary flaxseed meal is more protective than soy protein concentrate against hypertriglyseridemia and steatosis of the liver in a animal model of obesity. J Am Coll Nutr. 2003; 22: 157-64.

15. Koshy AS. Anila L. Vijayalakshmi NR. Flavonoids from Garcinia cambogia lower lipid levels in hypercholesterolemic rats. Food Chem. 2001; 72: 289-94.

16. Nishi T. Hara H. Tomita F. Soybean beta-conglycinin peptone suppresses food intake and gastric emptying by increasing plasma cholecystokinin levels in rats. Northern Advancement Center for Science and Technology. Colabo-Hokkaido. Sapporo 001-0021. 2003. Japan.

17. Nishi T. Hara H. Hira T \& Tomita F. Dietary protein peptic hydrolysates stimulate cholecystokinine release via direct sensing by rat intestinal mucosal cells. Exp Biol Med.2001; 226: 1031-6.

18. Xiao CW. Health effects of soy protein and isoflavones in humans, evidence for health claims on food: How much is enough?. J Nutr. 2008; 138: 1244S-9S.

19. Paillasse MR, de Medina P, Amouroux G, Mhamdi L, Poirot $M$ and Silvente-Poirot S. 'Signaling through cholesterol esterification: a new pathway for the cholecystokinin 2 receptor involved in cell growth and invasion. J Lipid Res. 2009 Nov; 50(11): 2203-11.

20. Erdman JW. Soy protein and cardiovascular disease. A statement for healthcare professionals from the nutrition committee of the American Heart Association (AHA). Circulation. 2000; 102: 2555-9

21. UnitedSoyBoard.http://www.soyconnection.com/soyfoods/ soy_lecithin_facts.php.8 Januari 2011. 